\title{
CONCERNING EDENTTELLINA.
}

\section{By Charles Hedley, F.L.S.}

Read 9th April, 1920.

The Australian fauna is remarkable for its wealth of oddities, and in the Pelecypoda this quality is expressed by several excentric forms such as Clëdothcerus, Dimya, Ephippodonta, Foramelina, Myochama, Pseudochama, and Neotrigonia. To this assemblage is now added Edenttellina.

A small strange bivalve was once found by Deshayes among the Eocene fossils of the Paris Basin. It took the form of a thin and depressed scale ; on the umbo of the left valve was planted a spiral nucleus like the tip of the gasteropod Strebloceras, the hinge of the right valve carried a small cardinal tooth, and no muscular impressions were perceptible. He had intended to present it as a new genus, Ludovicia, and to place it next to Pandora.

Deshayes, however, never finished his work and the little shell lay unpublished for a generation, until Maurice Cossmann in 1888 described and figured it as Ludovicia squamula. ${ }^{1}$ He differed from Deshayes in his estimate of its relationship and proposed to bestow the genus in the family Galeommidæ. Mr. W. J. Wintle kindly points out to me that Ludovicia is presccupied by Ludovicius, proposed by C. Rondani (Nuov. Ann. Sci. Nat., Bologna, vol. x, 1843 , p. 43). According to Marschall the same name was afterwards (Isis, 1845 , p. 719) rendered as Ludovicia.

Dredging within the Great Barrier Reef in August, 1906, I obtained numerous specimens as disassociated valves of a small shell which was provisionally labelled as Ludovicia, sp., and laid aside for further consideration. Meanwhile, a related form had been taken more than a thousand miles away, near Melbourne, and by Messrs. Gatliff and Gabriel was described and figured as Edenttellina typica. Sir Joseph Verco, who had previously made the acquaintance of the species, then announced that it also occurred in South Australia.

The present writer commented on the absence from Edenttellina of characteristic pelecypod features and suggested that possibly it might be the internal shell of a tectibranch; the likeness between the Parisian fossil Ludovicia and the recent Australian shell was also noticed.

Recent discoveries by Sir Joseph Verco have solved the problem as to which class the perplexing stranger belongs. At Guichen Bay, in South Australia, he procured better material than had been studied by the Melbourne naturalists. This showed the right and left valves to be united by a ligament and thus satisfactorily established

1 Cossmann, Mém. Soc. Roy. Malac. Belg., vol. xxii, 1887 (1888), p. 45, pl. ii, figs. 2!-22. 

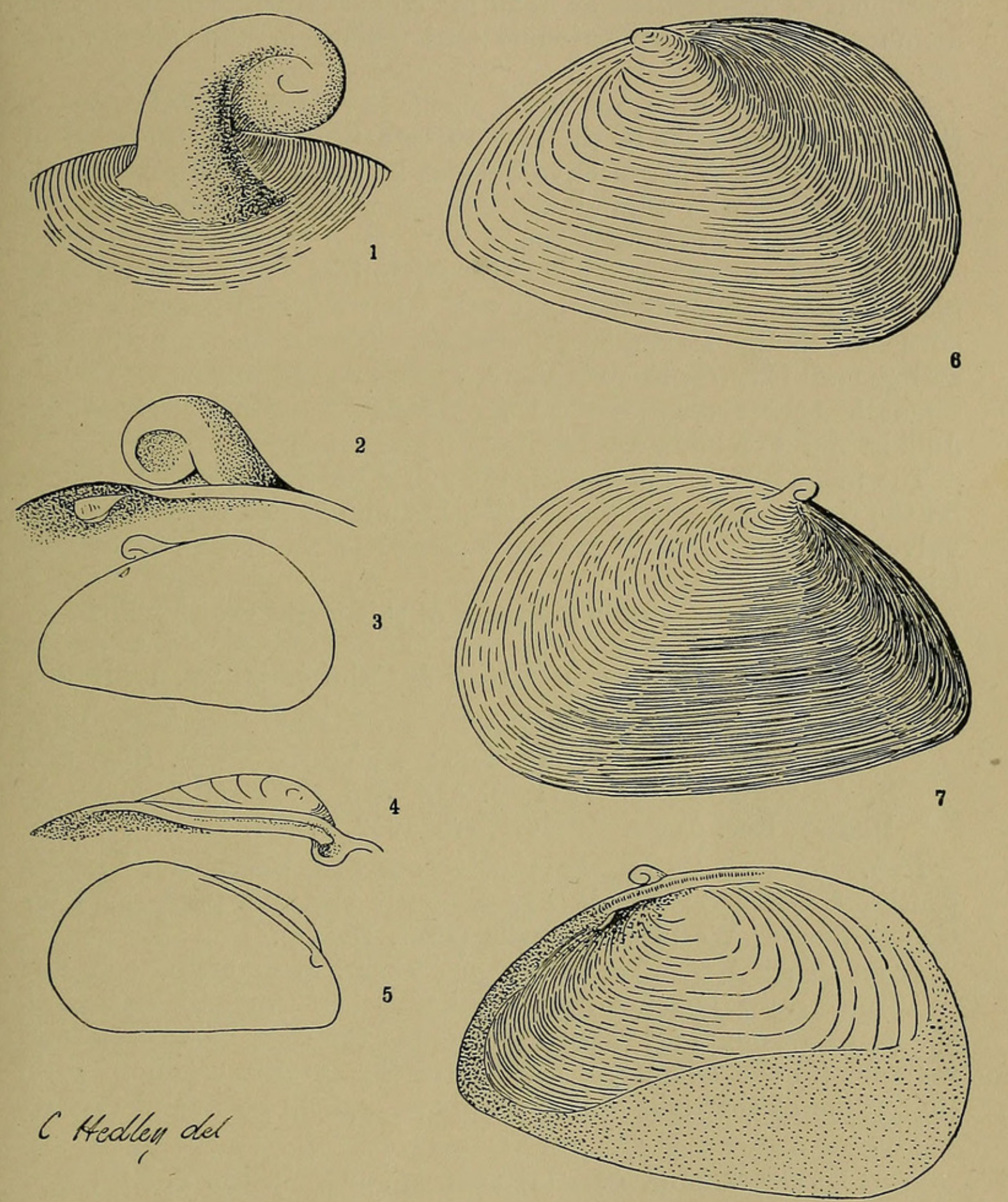

CHedlen del

FIGS. 1-5.-Edenttellina typica, Gatliff \& Gabriel.

,, 6-8.-Edenttellina corallensis, n.sp. 
the pelecypod nature of the shell. The hinge was also shown to contain "valid anterior teeth".

By the kindness of Mr. Ph. Dautzenberg I enjoyed an opportunity of examining cotypes of $L$. squamula in his collection. Not having specimens of Edenttellina at hand for comparison I had to rely on memory, but my recollection is that Ludovicia and Edenttellina are co-generic.

The situations in which dead shells have been found indicate that the species lives in shallow water a little below the level of low tide. The soft parts have not yet been seen by any zoologist. On a study of the animal will depend a final judgment of the taxonomic position of the genus.

So far as I am aware, it has not been noticed that Julia exquisita carries on the umbo of the right valve, but not on the left, a spiral horn, like, though far smaller, that of Edenttellina. In hinge structure and general features there is also a general correspondence. On the strength of these resemblances I would refer Edenttellina to the family Juliidæ (= Prasinidæ of Fischer's "Manuel ").

The inequality of the valves, the spiral prodissoconch sometimes on the right, sometimes on the left, but unmatched in the opposite valve, and the massive cardinal suggests to me some relationship with the Chamacea.

The two recent Australian species of this genus are as follows :-

Edenttellina typica, Gatliff \& Gabriel. (Figs. 1-5.)

Edenttellina typica, Gatliff \& Gabriel, Proc. Roy. Soc. Vict., xxiv, 1911, p. 190, pl. xlvi, figs. 5-6; id. Verco, Trans. Roy. Soc. S. Australia, xxxvi, 1911 , p. 328 , and xl, 1916, p. 596 ; id. Hedley, Rec. Austr. Museum, viii, 1912, p. 134.

Hab.-Portsea (type), Point Nepean, and Shoreham, Victoria (Gatliff \& Gabriel); Guichen Bay, South Australia (Verco); King George Sound, Western Australia (Prof. Dakin).

From South Australian specimens, $5 \mathrm{~mm}$. in diameter, collected in 1916 at Robe, Guichen Bay, and kindly lent to me by Sir Joseph Verco, I now figure (1) the spiral umbo of the right valve seen from without, (2) the same from within and the anterior cardinal tooth, (3) outline of the right valve, (4) hinge, and (5) outline of the left valve.

Edenttellina corallensis, sp. nov. (Figs. 6-8.)

Compared with the preceding species, this has the valve more solid, more compressed, and more pointed anteriorly. The colour is pale sulphur yellow. Length 5 , height 3 , depth of single valve $1.3 \mathrm{~mm}$.

$H a b$. Coral mud, in 5 to 10 fathoms off the Hope Islands, North Queensland, where I dredged several separate valves in August, 1906. 


\section{$2 \mathrm{BHL}$ Biodiversity Heritage Library}

1920. "Concerning Edenttellina." Proceedings of the Malacological Society of London 14, 74-76. https://doi.org/10.1093/oxfordjournals.mollus.a063724.

View This Item Online: https://www.biodiversitylibrary.org/item/95719

DOI: https://doi.org/10.1093/oxfordjournals.mollus.a063724

Permalink: https://www.biodiversitylibrary.org/partpdf/69316

\section{Holding Institution}

Smithsonian Libraries

\section{Sponsored by}

Smithsonian

\section{Copyright \& Reuse}

Copyright Status: Public domain. The BHL considers that this work is no longer under copyright protection.

This document was created from content at the Biodiversity Heritage Library, the world's largest open access digital library for biodiversity literature and archives. Visit BHL at https://www.biodiversitylibrary.org. 